\title{
Effects of Seahorse Supplementation for 6 Weeks on Muscle Mass, Muscle Fitness, and Exercise Performance Abilities in Elderly
}

\author{
Byeong Hwan Jeon ${ }^{1 *}$
}

${ }^{1}$ Kyungsung University

Received: October 31, 2018

Accepted: December 18, 2018

Published online: January 31, 2019

Keywords:

Elderly

Exercise Performance Abilities

Muscle Mass

Muscle Fitness

Seahorse Supplementation

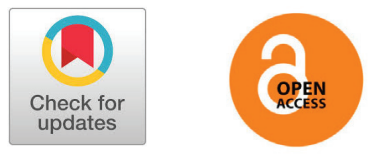

\section{ABSTRACT}

OBJECTIVES Base on the series of findings for seahorse supplementation of our group, we were supposed to investigate the effects of seahorse extract supplementation for 6 weeks on muscle mass, muscle fitness, and the ability of daily life and exercise performance in elderly.

METHODS The elderly were divided into SHD(seahorse diet, $n=27$ ) and CON(control, $n=26$ ) group and supplemented with $1,000 \mathrm{mg} /$ day of seahorse extract for 6 weeks. Before and after 6 week of treatments, they were observed changes in body composition and muscle mass, muscle strength and endurance, the exercise performance abilities including cardiac function and autonomic nervous system activity, static and dynamic stabilities, and blood variables.

RESULTS After the 6 week of seahorse supplementation in elderly, 1 ) it has been shown the quantitative and qualitative improvement within muscle by increased total lean body(muscle) mass, weight bearing muscle endurance, isokinetic muscle endurance; 2) An in static stability showed improved by increased in one leg standing time. A decrease in heart rate and an increase in SDNN showed partial improvement of the autonomic nervous system; 3 ) There was partial improvement on the blood metabolism functions by a decrease in blood lactate levels and an increase in HDL cholesterol.

CONCLUSIONS These changes suggest that the 6-week of seahorse supplementation may improve in muscle mass and fitness, and the ability of daily life and exercise performance in elderly.

(c) The Asian Society of Kinesiology and the Korean Academy of Kinesiology

\section{서론}

노화가 진행되면서 낙상의 위험은 시력과 균형감각 능력, 보행 능력, 일상생활 능력 등의 기능장애, 운동부 족이나 골절 후유 질환 등의 위험요인에 따라 증가하고, 특히 근육계와 신경계의 퇴행에 따른 근기능 약화와 평 형성의 문제가 결정적인 원인이 될 수 있다. 노화에 따른 낙상 가능성이 증가하면서, 실제로 최근에 조사를 통해 우리나라 노인의 신체손상 중에서 낙상 비율이 절반 이

*Correspondence: Byeong Hwan Jeon, Sports and health science, Kyungsung University, 309 Suyung-ro, Busan, Republic of Korea; Tel: +82-51-663-4951; Fax : +8251-663-4959; E-mail: mooaworld@ks.ac.kr
상을 차지하는 것으로 확인됐다[1]. 근육량은 50세 이 후 10년마다 5-10\% 감소하고, 근력은 50세 이후에 10 년마다 $15 \%$ 감소하고 70 세에 이르면 10년마다 $30 \%$ 씩 감소하는 것으로 나타났다[2]. 이러한 근감소증 현상은 상대적으로 근육량은 낮으면서도 인구학적으로 노인이 급격히 증가하고 있는 우리나라에서는 영향력 높은 사 회문제가 될 수 있다.

노화가 진행되면서 일상생활이나 여러 활동 수준을 결정하는 근육 및 신경 조직의 퇴행은 불가피하지만, 다 행이 식이섭취나 운동처치 등의 의료적 치료 부담이 없 이도 생활습관의 변화를 통해서 그 진행을 어느 정도 지 
연시키거나 완화시킬 수 있다[3,4]. 이러한 생활습관의 개선에 따른 근육의 변화는 근신경변화에 다른 근력 증 가와 근육량의 증가에 따른 근력의 증가 등의 질적 및 양적 개선의 단계를 갖는다. 특히, 식이보조섭취를 통 한 근육량과 근기능, 기능성 체력과 운동수행능력의 단 계적 퇴행을 예방하는 근거를 제시하기 위해서는 근육 의 양적 변화와 질적 변화를 구분하여 분석하고 효과를 확인하는데 운동과학적 접근이 요구된다.

해마(hippocampus)는 근해에 서식하는 실고기과 경골어류로서, 전통적인 약재로 사용되고있다. 최근 관련된 연구를 통해 해마는 약 $58 \%$ 의 단백질(crude protein)과 $2.6 \%$ 의 지질(crude lipid)를 포함하는 고단 백식품소재로서, 지표성분의 작용기작(간기능성 개선, 근력강화, 정자 운동성 개선)과 주요 활성기능을 바탕 으로 [5-7], 항암, 항노화 등의 성인 질환, 스테미너 등 에 대한 긍정적 효능을 갖는 것으로 알려져 있다[8].

이러한 연구결과들을 기초로, 해마 보조섭취는 운동 수행능력에 관련된 여러 중요 지표에 대한 순기능적 효 과를 가질 가능성이 높을 것으로 예상되지만 이와 관련 된 연구는 매우 부족한 실정이며 - 특히 신체기능의 퇴 행으로 해당 효능이 절실히 필요한 노인을 대상으로 신체구성과 근기능, 운동수행능력 개선에 대한 해마 유 효성분의 효능 검증과 정립이 필요하다.

이러한 필요성을 배경으로, 우리 그룹은 해마의 지표 성분의 효능에 관한 일련의 사전연구들을 통해 신체구 성과 운동수행능력 등의 개선 효과들을 검증하고 있으 며, 최근에는 분말 형태의 해마추출물을 8 주간 보조 섭 취하여 운동 수행능력 관련인자들에 대한 긍정적인 효 과를 확인한 바 있다[9]. 최근에 수행한 일련의 임상적 용 연구결과를 근거로 하여, 이 연구에서는 운동능력과 관련된 신체의 구성과 기능의 개선효과가 나타날 수 있 는 해마의 최소 섭취기간을 6주로 선정하여 실제 일반 인에게 필요한 기능성식품으로 개발하는데 필요한 실용 성과 사업성을 과학적으로 검증하고자 하였다. 이때 섭 취량의 설정근거로서, 사전 동물실험에서 설정한 적정 섭취량을 인체 표면계수에 적용한 후, 인체적용 기능성 식품으로 개발하기 위하여 동물실험의 약 $50 \%$ 수준으 로 $1,000 \mathrm{mg} / \mathrm{day}$ 의 일일섭취량을 결정했다.

따라서 이 연구를 통해, 임상연구에 필요한 효과 크 기와 검정력을 고려한 표본 수준의 노인들을 대상으로, 6 주간 해마추출물 섭취가 근육량과 근체력, 일상생활능
력(ADL)을 포함한 운동수행능력을 개선하는 효과를 갖 는지를 구명하고자 한다.

\section{연구방법}

\section{연구대상}

65 세 이상의 건강한 노인들을 대상으로 하여, 피험자 수는 G Power 3.1 프로그램을 활용하여 t-test를 위한 양측 검정으로, 유의수준 .05, 집단수 2 , 효과크기 .50, 검정력 .80 을 조건으로 하여 각 집단별 26 명을 산출했 으며, 탈락률을 고려하여 60 명을 선정하여 무작위법으 로 집단을 배정했다. 이때 만성/퇴행성 질환과 개인 특 이적 질환자는 제외했다. 실험은 $\mathrm{K}$ 대학교 연구윤리위 원회로부터 승인된 절차(KSU-17-02-001-0414)에 따라 실시하였다. 기간 중 탈락자를 제외한 최종피험자 53 명의 신체적 특성은 <Table 1 >과 같다.

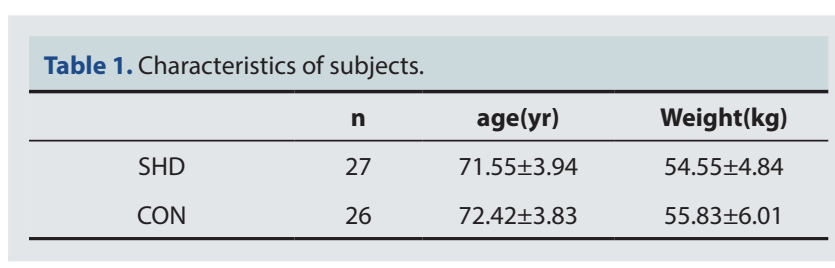

\section{측정항목 및 방법}

식이 처치 식이처치를 위한 시료는 해마추출물과 유 당 분말을 $1: 1(\mathrm{w} / \mathrm{w})$ 혼합한 캡슐형태로 제작했다. 최종 섭취량은 사전 동물 실험에서의 적정한 섭취량( $200 \mathrm{mg} /$ $\mathrm{kg}$ )을 인체의 체표면적(체표면적 대비 환산계수 0.16) 에 적용하여 $32 \mathrm{mg} / \mathrm{kgBW} / \mathrm{day}$ 으로 환산하고, 평균체중 $60 \mathrm{~kg}$ ( $1,920 \mathrm{mg} / \mathrm{day})$ 의 $50 \%$ 수준인 $1,000 \mathrm{mg} / \mathrm{day}$ 으 로 설정함으로써, 실제 기능성 식품으로 개발되기 위한 임상시험 조건으로 결정했다 [10].

신체조성과 근육량 근육량을 의미하는 총제지방질 량(total lean body mass)과 신체조성은 생체전기저 항측 정기(Inbody 720, Biospace, Korea)를 이용하 여 6 주간의 식이처치 전과 후에 12 시간 공복상태에서 측정했다. 측정된 값을 이용하여 골격근지수(skeletal muscle index, $\mathrm{SMI}\left(\mathrm{kg} / \mathrm{m}^{2}\right)$ =사지 근육량/키의 제곱 $\mathrm{X} 100)$ 를 산출했다.

\section{근체력}

근력 전신근력과 상관성이 높은 악력과 배근력 1 
$\mathrm{RM}($ repetition maximum)을 측정했다.

근지구력 윗몸일으키기와 무릎굽혀 팔굽혀펴기로 최 대 반복수(multiple RM)를 측정했다.

등속성 근력 하지 근육의 등속성근력은 등속성근력 측정시스템(Biodex syetem 4 Pro, Biodex, USA)을 이용하여 무릎 신전(extension)시 주동근인 대퇴사두 근(quadriceps)에서 60 degree/sec 및 180 degree/ $\mathrm{sec}$ 의 각속도로 등속성 근력을 측정했다.

\section{운동수행능력 관련 인자}

심폐기능과 자율신경계 활성도 심폐기능과 그에 따 른 자율신경계의 활성도는 BVP센서(IHM, CA, USA) 를 이용하여 분당심박수(HR)와 심박변이도를 통해 측정 했다. 표면센서로 5 분간 맥박정보를 획득하여 $\mathrm{HF}$ (high frequency), LF(low frequency), total power, SDNN (standard deviation of normal-to-normal intervals) 값을 도출했다. 이때 $\mathrm{HF}$ 와 $\mathrm{LF}$ 에서 맥박조절 자율신경 계 중 부교감신경계와 교감신경계의 상대적 긴장도를 의미하고, total power와 SDNN 에서 자율신경계의 전 반적인 활성도를 나타낸다 $[11,12]$.

평형성 노인 기능체력검사(senior fitness test)의 일 부로 낙상예방에 중요한 기능인 평형성을 검사했다. 1)양 손은 허리를 잡고 한쪽 다리씩 번갈아 들게 하여 자세를 유지하는 시간, 즉 한발서기시간으로 정적 평형성을 검사 했다. 2)정상적인 보행으로 $6 \mathrm{~m}$ 를 걸어갔다가 돌아오는데 걸리는 보행시간으로 동적 평형성을 검사했다.

혈액변인 6 주간의 식용해마섭취 전과 후 시점에서 안 정시 전완정맥에서 $12 \mathrm{ml}$ 를 채혈한 후, $1,000 \mathrm{~g}$ 에서 15 분 동안 원심분리로 혈장 및 30 분간 혈액응고시킨 혈청을 분리했다.

혈중 젖산(lactate)은 젖산 분석기에서 흡광도를 이 용하여 농도를 측정했다. 혈당(glucose)은 표준 혈당측 정기를 사용하여 측정했다. 혈중 중성지방 $(\mathrm{TG}$, triglyceride)은 효소분광법을 이용한 흡광도 측정법으로 분석했다. 혈중 콜레스테롤(cholesterol)은 혈중 LDL과 $\mathrm{HDL}$ 각각의 농도를 분리한 혈장으로 흡광분석법을 이용 하여 측정했다. 혈장 내 크레아틴(creatine) 함량은 Jaffe reaction을 이용한 흡광도측정법으로 분석했다.

\section{통계처리}

실험결과는 SPSS(Ver 20.0) 통계프로그램을 이용하
여 각 집단별 측정항목의 평균 $(\mathrm{M})$ 과 표준편차 $(\mathrm{M} \pm \mathrm{SD})$ 를 산출했으며, 각 군의 유의성 검정은 집단간 차이 및 집단내 사전사후 변화를 독립 t-test 및 종속 t-test를 이용했다. 유의수준(a)은 .05로 설정했다.

\section{결과}

\section{신체조성과 근육량의 변화}

6 주간의 식용해마의 섭취에 따른 변화를 신체조성별 로 구분하여 분석한 결과는 〈Figure 1$\rangle$, 〈Table 2, 3〉 과 같다. 6주간의 소재 섭취 후 총제지방량(total lean mass, $\mathrm{kg}$ )에서 $\mathrm{SHD}$ 군은 $0.32 \pm .46$ 증가하였고 $\mathrm{CON}$ 군은 $0.02 \pm .67$ 감소하여 두집단 간에서 통계적 유의한 차이를 보였다( $\mathrm{p}=.032)$. SHD군 내에서는 $19.67 \pm 2.00$ 에서 $19.87 \pm 1.98$ 로 유의한 증가를 나타냈다 $(\mathrm{p}=.047)$.

\begin{tabular}{|c|c|c|c|c|c|}
\hline Variable & Group & Pre & Post & $\mathbf{t}$ & $\mathbf{p}$ \\
\hline \multirow{2}{*}{ weight(kg) } & SHD & $54.55 \pm 4.84$ & $54.97 \pm 4.53$ & -1.983 & .058 \\
\hline & CON & $55.83 \pm 6.01$ & $57.76 \pm 6.22$ & -1.953 & .062 \\
\hline \multirow{2}{*}{$\begin{array}{l}\text { total lean } \\
\text { mass(kg) }\end{array}$} & SHD & $19.67 \pm 2.00$ & $19.87 \pm 1.98$ & -2.08 & .047 \\
\hline & CON & $20.48 \pm 1.58$ & $20.46 \pm .56$ & .175 & .862 \\
\hline \multirow{2}{*}{$\begin{array}{l}\text { total fat } \\
\text { mass(kg) }\end{array}$} & SHD & $17.80 \pm 4.02$ & $17.87 \pm 4.08$ & -.466 & .645 \\
\hline & CON & $18.50 \pm 4.79$ & $19.15 \pm 3.80$ & -.930 & .361 \\
\hline \multirow{2}{*}{$\begin{array}{c}\text { SMI }(\mathrm{kg} / \\
\left.\mathrm{cm}^{2}\right)\end{array}$} & SHD & $5.31 \pm .66$ & $5.38 \pm .64$ & -1.626 & .116 \\
\hline & CON & $5.21 \pm .53$ & $5.14 \pm .53$ & 2.079 & .058 \\
\hline
\end{tabular}

* SMI: skeletal muscle index

Table 3. Comparison of Body composition variables between SHD and CON groups

\begin{tabular}{ccccc}
\hline Variables & SHD(n=27) & CON(n=26) & t & P \\
\hline weight $(\mathrm{kg})$ & $1.02 \pm .56$ & $1.93 \pm 5.05$ & -.929 & .357 \\
total lean mass $(\mathrm{kg})$ & $.32 \pm .46$ & $-.02 \pm .67$ & 2.201 & .032 \\
fat mass $(\mathrm{kg})$ & $.07 \pm .78$ & $.65 \pm 3.58$ & -.826 & .413 \\
$\mathrm{SMI}\left(\mathrm{kg} / \mathrm{cm}^{2}\right)$ & $.03 \pm .22$ & $-.06 \pm .17$ & 1.880 & .066 \\
\hline
\end{tabular}

SMI: skeletal muscle index

반면, 6 주간의 식용해마 섭취 후 체중에서의 집단간 및 집단내 변화가 나타나지 않았다. 총지방량(total fat mass, $\mathrm{kg}$ )은 6주간의 식용해마 섭취 후 집단 간에서 유 의미한 변화가 발견되지 않았고( $\mathrm{p}=.413)$, 또한 SHD군 $(\mathrm{p}=.645)$ 및 $\mathrm{CON}$ 군 $(\mathrm{p}=.361)$ 모두 집단내 사전대비 사 후변화에서 모두 유의한 차이가 나타나지 않았다. 골격 

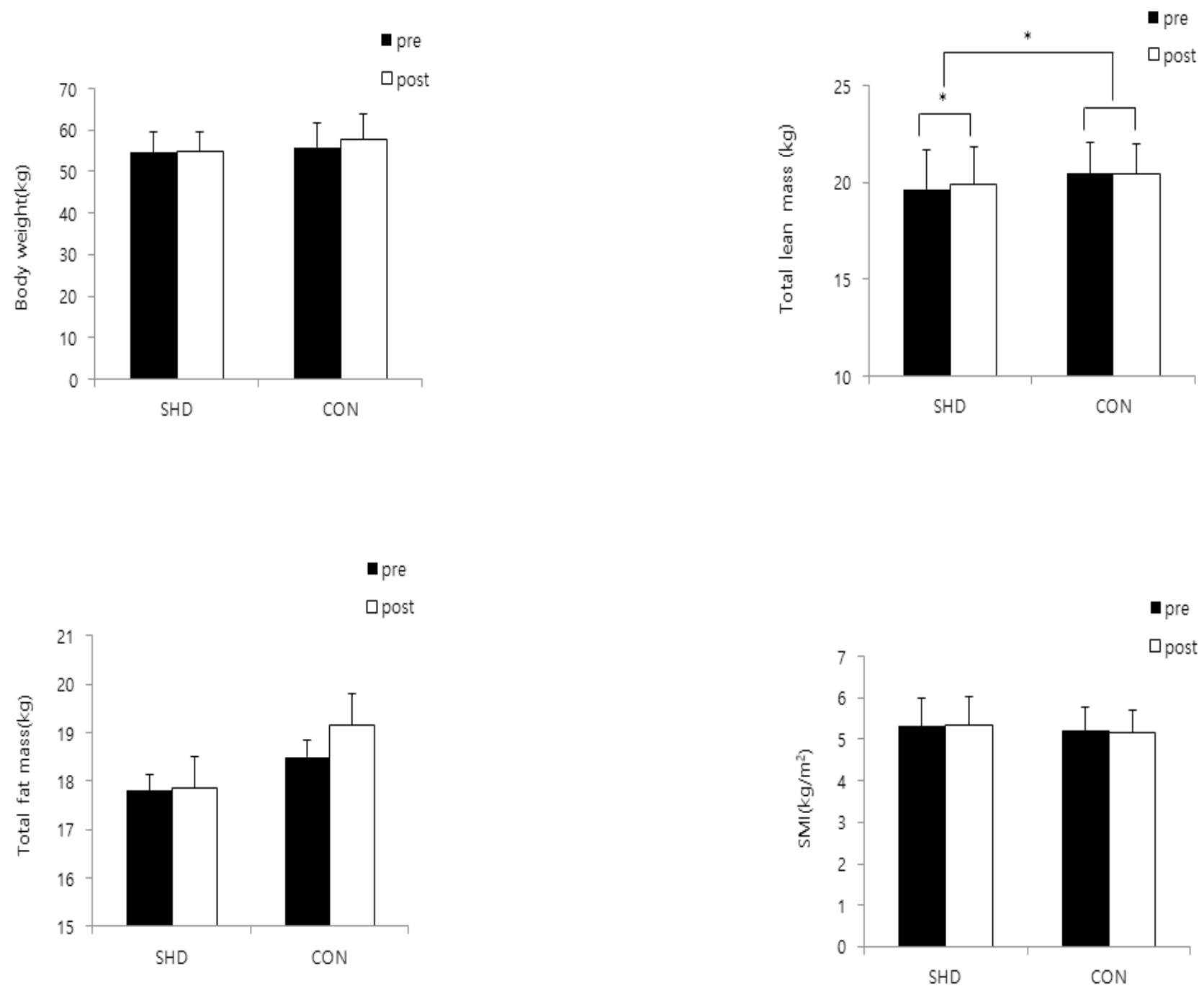

Figure 1. Effect of seahorse extract diet for 6 weeks on body composition and muscle mass in elderly. $\left({ }^{*} \mathrm{p}<.05\right)$

근 지수 $\left(\mathrm{SMI}\left(\mathrm{kg} / \mathrm{cm}^{2}\right)\right)$ 에서도 6주간의 식품 소재 섭 취 후 두 집단간 유의차가 나타나지 않았으며 $(\mathrm{p}=.066)$, 집단내의 사전대비 사후변화에서도 $\operatorname{SHD}$ 군 $(\mathrm{p}=.116)$ 과 $\mathrm{CON}$ 군 $(\mathrm{p}=.058)$ 모두 유의한 차이가 나타나지 않았다.

\section{근체력의 변화}

6 주간의 기능성 소재 섭취 전후의 근력(악력, 배근 력) 및 근지구력(윗몸일으키기, 팔굽혀펴기)의 변화를 각각 관찰했다 <Figure 2$\rangle$, 〈Table 4, 5>.

윗몸일으키기(회) 6 주간의 식품 소재 섭취 후 SHD 군은 $.407 \pm 1.00$ 증가하였고 $\mathrm{CON}$ 군은 $0.11 \pm .81$ 감 소하여, 집단 간에서 통계적 유의한 차이를 보였다 ( $\mathrm{p}=.044)$. 집단내에서는 $\mathrm{SHD}$ 군 내에서는 $11.29 \pm 6.50$ 에서 $14.03 \pm 4.78$ 로 유의한 증가를 나타냈다 $(\mathrm{p}=.046)$.
$\mathrm{CON}$ 군 내에서는 통계적으로 유의한 변화가 없었다 $(\mathrm{p}=.478)$.

Table 4. Comparison of muscular strength and endurance variables within SHD and CON groups

\begin{tabular}{cccccc}
\hline Variable & Group & Pre & Post & t & p \\
\hline \multirow{2}{*}{ Sit-up } & SHD & $11.29 \pm 6.50$ & $14.03 \pm 4.78$ & -2.096 & .046 \\
& CON & $13.38 \pm 4.74$ & $13.26 \pm 4.64$ & .721 & .478 \\
& & & & & \\
Push-up & SHD & $5.22 \pm 2.04$ & $5.48 \pm 1.80$ & -1.492 & .148 \\
& CON & $4.96 \pm 2.61$ & $5.19 \pm 2.74$ & -1.030 & .313 \\
Grip & SHD & $19.96 \pm 3.48$ & $20.11 \pm 3.52$ & -.811 & .425 \\
strength(kg) & CON & $20.38 \pm 3.02$ & $20.34 \pm 2.81$ & .146 & .885 \\
Back & SHD & $43.51 \pm 11.17$ & $44.00 \pm 10.88$ & -.796 & .433 \\
strength $(\mathrm{kg})$ & CON & $42.34 \pm 9.28$ & $41.50 \pm 10.23$ & 1.281 & .212 \\
\hline
\end{tabular}



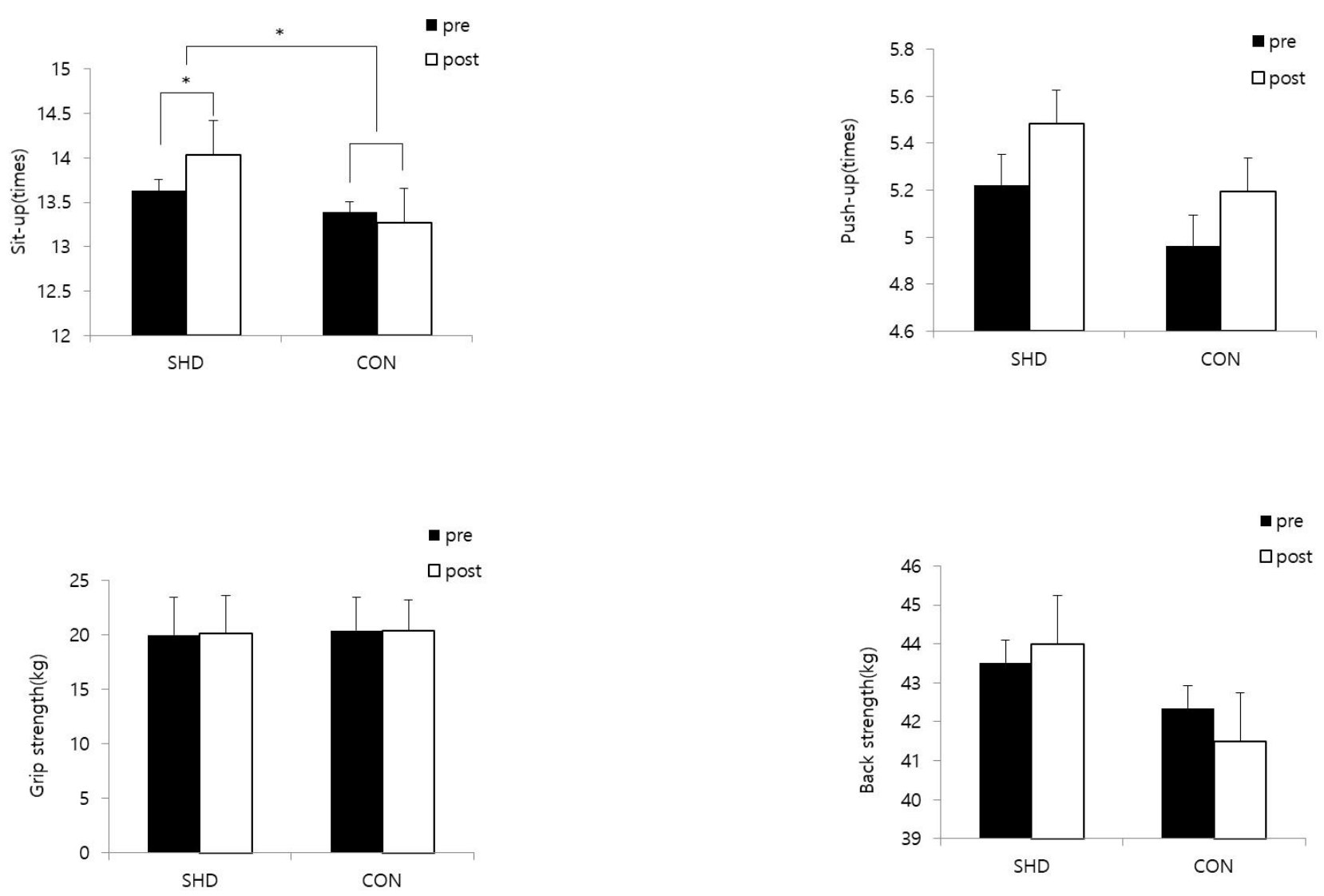

Figure 2. Effect of seahorse extract diet for 6 weeks on muscular strength and endurance in elderly. $\left({ }^{*} \mathrm{p}<.05\right)$

Table 5. Comparison of muscular strength and endurance variables between SHD and CON groups

\begin{tabular}{ccccc}
\hline Variables & $\mathbf{S H D}(\mathbf{n}=\mathbf{2 7})$ & $\mathbf{C O N}(\mathbf{n}=\mathbf{2 6})$ & $\mathbf{t}$ & $\mathbf{p}$ \\
\hline Sit-up & $.407 \pm 1.00$ & $-.11 \pm .81$ & 2.068 & .044 \\
Push-up & $.25 \pm .90$ & $.20 \pm 1.15$ & .207 & .837 \\
Grip strength(kg) & $.48 \pm .89$ & $-.03 \pm 1.34$ & 1.667 & .102 \\
Back strength(kg) & $.48 \pm 3.14$ & $-.84 \pm 3.14$ & 1.485 & .144 \\
\hline
\end{tabular}

팔굽혀펴기(회) 6주간의 식품 소재 섭취 후 처치 집 단간 통계적 유의한 차이를 보이지 않았다 $(\mathrm{p}=.837)$. 한 편, 집단내 사전대비 사후변화에서 유의한 차이가 나타 나지 않았다.

악력(kg) 6주간의 식품 소재 섭취 후 집단 간에서 통 계적으로 유의한 차이가 나타나지 않았다 $(\mathrm{p}=.102)$. 한 편, 집단내 사전대비 사후변화에서도 유의한 차이가 없 었다.
배근력 $(\mathbf{k g})$ 6주간의 식품 소재 섭취 후 SHD군은 $0.48 \pm 3.14$ 증가하였고, $\mathrm{CON}$ 군은 $0.84 \pm 3.14$ 감소하 는 경향이 나타났지만 통계적 유의차는 없었다( $\mathrm{p}=.144)$. 한편, 집단내 사전대비 사후변화에서 모두 유의한 차이 가 나타나지 않았다.

\section{등속성 근력의 변화}

6주간의 기능성 소재 섭취 전후의 집단별 등속성 근 력의 변화를 $60 \mathrm{deg} / \mathrm{sec}$ 와 $180 \mathrm{deg} / \mathrm{sec}$ 에서 분석한 결 과는 〈Figure 3$\rangle$, 〈Table 6, 7>와 같다.

Table 6. Comparison of isokinetic muscular strength within SHD and CON groups

\begin{tabular}{cccccc}
\hline Variable & Group & Pre & Post & $\mathbf{t}$ & $\mathbf{p}$ \\
\hline $60 \mathrm{deg} /$ & SHD & $75.31 \pm 13.56$ & $78.14 \pm 15.68$ & -1.583 & .126 \\
$\sec (\mathrm{Nm})$ & CON & $81.55 \pm 16.09$ & $84.93 \pm 16.57$ & -1.133 & .268 \\
& & & & & \\
$180 \mathrm{deg} /$ & SHD & $78.42 \pm 17.03$ & $82.32 \pm 16.21$ & -2.059 & .050 \\
$\sec (\mathrm{Nm})$ & CON & $92.90 \pm 22.13$ & $90.76 \pm 18.90$ & -.910 & .372 \\
\hline
\end{tabular}




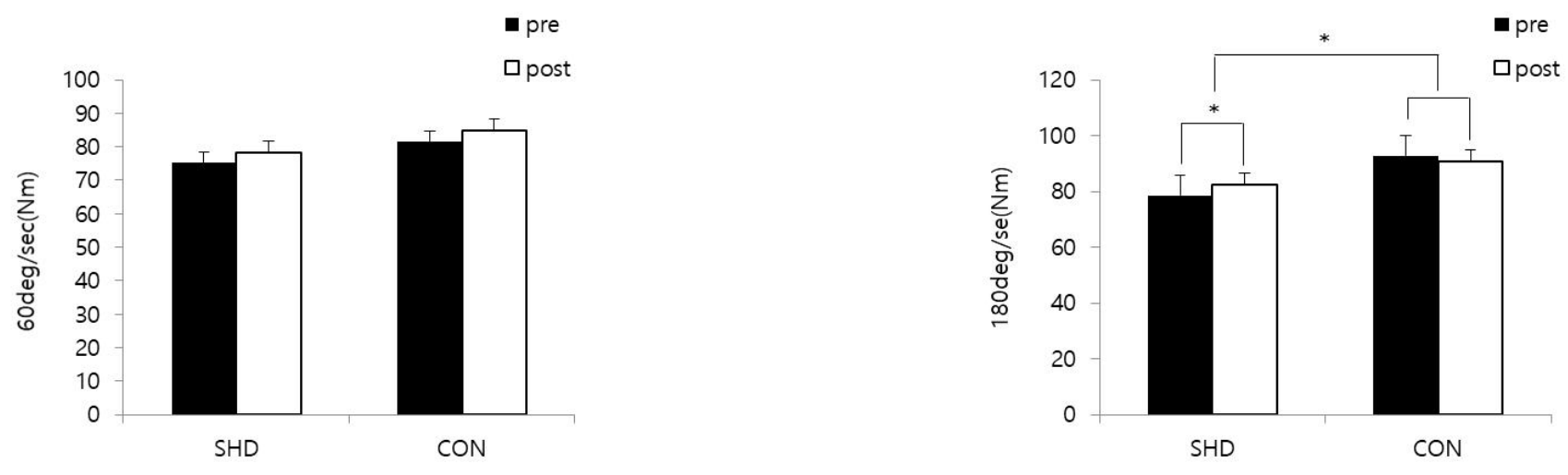

Figure 3. Effect of seahorse extract diet for 6 weeks on isokinetic muscular strength in elderly. $\left({ }^{*} \mathrm{p}<.05\right.$.)

Table 7. Comparison of isokinetic muscular strength between SHD and CON groups

\begin{tabular}{ccccc}
\hline Variables & SHD(n=27) & CON(n=26) & $\mathbf{t}$ & $\mathbf{p}$ \\
\hline $60 \mathrm{deg} / \mathrm{sec}(\mathrm{Nm})$ & $2.83 \pm 9.31$ & $3.38 \pm 15.23$ & -.159 & .875 \\
$180 \mathrm{deg} / \mathrm{sec}(\mathrm{Nm})$ & $3.89 \pm 9.84$ & $-1.98 \pm 11.47$ & 2.040 & .047 \\
\hline
\end{tabular}

60deg/sec 6주간의 식품 소재 섭취 후 SHD군과 $\mathrm{CON}$ 군의 두집단 간에 통계적으로 유의한 변화가 나타 나지 않았고 $(\mathrm{p}=.875)$, 집단내에서도 $\operatorname{SHD}$ 군 $(\mathrm{p}=.126)$ 과 $\mathrm{CON}$ 군(p=.268) 모두 6주간 섭취 전후비교에서 유의한 차이가 나타나지 않았다.

$180 \mathrm{deg} / \mathrm{sec} 6$ 주간의 식품 소재 섭취 후 SHD군은 $3.89 \pm 9.84$ 증가하였고 $\mathrm{CON}$ 군은 $1.98 \pm 11.47$ 감소하 여, 두 처치집단 간에 통계적으로 유의한 결과를 나타 내었다 $(\mathrm{p}=.047)$. 집단내에서는 $\mathrm{SHD}$ 군에서는 6 주간 섭 취전 78.42 17.03 에서 섭취후 $82.32 \pm 16.21$ 로 유의 한 증가를 나타냈다 $(\mathrm{p}=.05)$. 반면 $\mathrm{CON}$ 군에서는 섭취 전후비교에서 유의한 차이가 나타나지 않았다 $(\mathrm{p}=.372)$.

\section{심폐기능과 자율신경계 활성도의 변화}

6 주간의 기능성 소재 섭취 전후의 집단별 심폐기능 과 자율신경계 활성도를 분석한 결과는 <Figure 4 >, $<$ Table 8, 9>과 같다.

심박수(beat/min) SHD군은 $1.90 \pm 6.29$ 증가하였 고 $\mathrm{CON}$ 군은 $3.23 \pm 8.57$ 감소하여 두 처치집단 간에 통 계적으로 유의한 결과를 나타내었다 $(\mathrm{p}=.016)$. 하지만 각 집단내 사전대비 사후 변화에서는 $\operatorname{SHD}$ 군 $(\mathrm{p}=.129)$ 과 $\operatorname{CON}$ 군 $(\mathrm{p}=.066)$ 모두에서 유의한 차이가 나타나지 않았다.
Table 8. Comparison of cardiac function and activity of the autonomic nervous system within SHD and CON groups

\begin{tabular}{cccccc}
\hline Variable & Group & Pre & Post & $\mathbf{t}$ & $\mathbf{p}$ \\
\hline $\mathrm{HR}(\mathrm{bpm})$ & $\mathrm{SHD}$ & $70.60 \pm 6.57$ & $72.50 \pm 7.38$ & -1.570 & .129 \\
& $\mathrm{CON}$ & $74.82 \pm 10.58$ & $71.59 \pm 7.46$ & 1.921 & .066 \\
$\mathrm{LF}\left(\mathrm{ms}^{2} /\right.$ & $\mathrm{SHD}$ & $242.58 \pm 123.32$ & $234.85 \pm 312.38$ & .133 & .895 \\
$\mathrm{~min})$ & $\mathrm{CON}$ & $207.79 \pm 167.55$ & $215.23 \pm 129.45$ & -.177 & .861 \\
$\mathrm{HF}\left(\mathrm{ms}^{2} /\right.$ & $\mathrm{SHD}$ & $186.51 \pm 112.41$ & $271.97 \pm 293.85$ & -1.414 & .169 \\
$\mathrm{~min})$ & $\mathrm{CON}$ & $192.59 \pm 82.67$ & $215.23 \pm 129.45$ & .773 & .446 \\
$\mathrm{SDNN}\left(\mathrm{ms}^{2} /\right.$ & $\mathrm{SHD}$ & $33.76 \pm 7.85$ & $38.78 \pm 14.48$ & -1.528 & .139 \\
$\mathrm{~min})$ & $\mathrm{CON}$ & $39.50 \pm 10.31$ & $28.65 \pm 6.01$ & 4.572 & .001 \\
\hline
\end{tabular}

Table 9. Comparison of cardiac function and activity of the autonomic nervous system between SHD and CON groups

\begin{tabular}{ccccc}
\hline Variables & $\mathbf{S H D}(\mathbf{n}=\mathbf{2 7})$ & $\mathbf{C O N}(\mathbf{n}=\mathbf{2 6})$ & $\mathbf{t}$ & $\mathbf{p}$ \\
\hline $\mathrm{HR}(\mathrm{bpm})$ & $1.90 \pm 6.29$ & $-3.23 \pm 8.57$ & 2.491 & .016 \\
$\mathrm{LF}\left(\mathrm{ms}^{2} / \mathrm{min}\right)$ & $-7.73 \pm 302.58$ & $7.44 \pm 214.68$ & -.210 & .835 \\
$\mathrm{HF}\left(\mathrm{ms}^{2} / \mathrm{min}\right)$ & $85.46 \pm 313.99$ & $-15.03 \pm 99.09$ & 1.558 & .125 \\
$\mathrm{SDNN}(\mathrm{ms} / \mathrm{min})$ & $5.02 \pm 17.07$ & $-10.85 \pm 12.10$ & 3.891 & .001 \\
\hline
\end{tabular}

$\mathrm{LF}\left(\mathrm{ms}^{2} / \mathrm{min}\right)$ 집간단 비교에서 $\mathrm{SHD}$ 군은 7.73 \pm 302.58 감소하였고 $\mathrm{CON}$ 군은 $7.44 \pm 214.68$ 증가하였지 만, 통계적 유의차는 없었다 $(\mathrm{p}=.835)$. 한편, 집단내 사전대 비 사후변화에서 모두 유의한 차이가 나타나지 않았다.

$\mathbf{H F}\left(\mathbf{m s}^{2} / \mathbf{m i n}\right) \quad \mathrm{SHD}$ 군은 $85.46 \pm 313.99$ 증가하였고 $\mathrm{CON}$ 군은 $15.03 \pm 99.09$ 감소하였지만, 통계적으로 유의미 한 변화는 없었다 $(\mathrm{p}=.125)$, 한편, 집단내 사전대비 사후변 화에서 모두 유의한 차이가 나타나지 않았다.

SDNN(ms $\left.{ }^{2} / \mathbf{m i n}\right) \mathrm{SHD}$ 군은 5.02 \pm 17.07 증가하였고 $\mathrm{CON}$ 군은 $10.85 \pm 12.10$ 감소하여 두 처치집단 간에 통계 

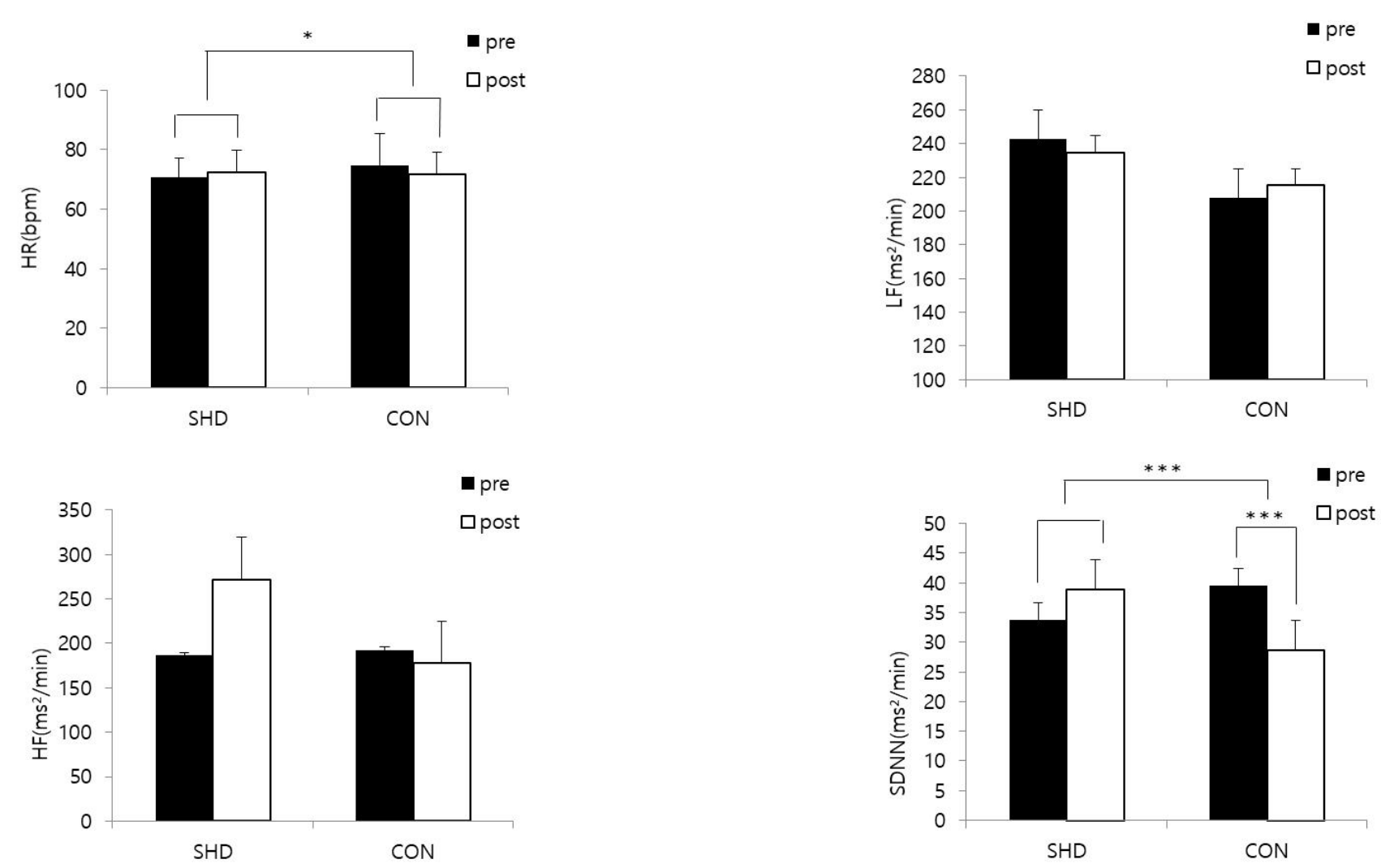

Figure 4. Effect of seahorse extract diet for 6 weeks on cardiac function and activity of the autonomic nervous system in elderly. $\left({ }^{* *} \mathrm{p}<.01,{ }^{* * *} \mathrm{p}<.001\right.$.)
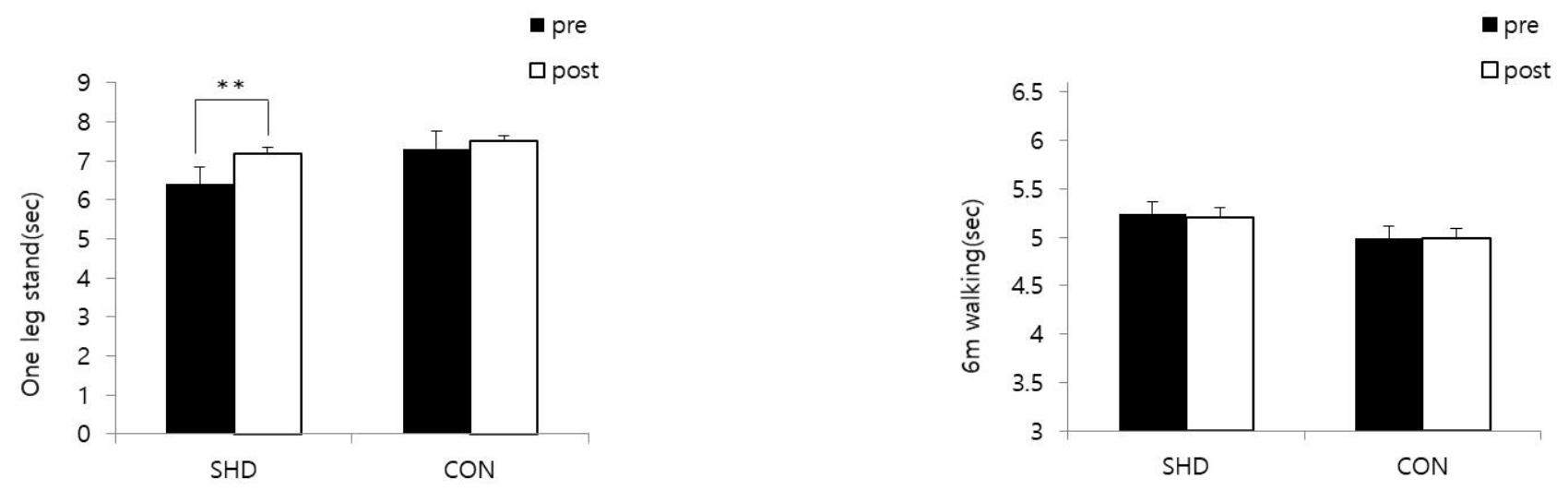

Figure 5. Effect of seahorse extract diet for 6 weeks on stabilities in elderly. $(* * p<.01)$

\section{평형성의 변화}

적으로 유의한 결과를 나타내었다 $(\mathrm{p}=.001)$. 한편, 집단내 사전대비 사후 변화에서는 $\mathrm{CON}$ 군이 $39.50 \pm 10.31$ 에서 $28.65 \pm 6.01$ 로 유의하게 감소하였고( $\mathrm{p}=.001)$, SHD군에서는 사전대비 사후 변화에서 유의차가 나타나지 않았다( $\mathrm{p}=.139$ ).
6주간의 기능성 소재 섭취 전후의 집단별 정적 평 형성과 동적 평형성의 변화를 분석한 결과는 <Figure $5>$, <Table 10,11>과 같다. 정적 평형성을 나타내는 한발서기 $(\mathrm{sec})$ 는 집단 간에서 통계적으로 유의한 차이 
가 나타나지 않았고( $\mathrm{p}=.154)$, SHD군의 사전대비 사후 변화는 $6.40 \pm 2.48$ 에서 $7.18 \pm 2.00$ 로 유의한 증가를 나 타냈다 $(\mathrm{p}=.011)$. 한편, 동적 평형성을 나타내는 $6 \mathrm{~m}$ 보 행시간 $(\mathrm{sec})$ 에서 집단 간의 유의차가 나타나지 않았다 $(\mathrm{p}=.744)$.

\begin{tabular}{|c|c|c|c|c|c|}
\hline Variable & Group & Pre & Post & $t$ & $p$ \\
\hline \multirow{2}{*}{$\begin{array}{c}\text { One-leg } \\
\text { standing(sec) }\end{array}$} & SHD & $6.40 \pm 2.48$ & $7.18 \pm 2.00$ & -2.738 & .011 \\
\hline & CON & $7.30 \pm 3.03$ & $7.50 \pm 3.33$ & -.667 & .511 \\
\hline \multirow{2}{*}{$\begin{array}{c}\text { 6m-walking } \\
(\mathrm{sec})\end{array}$} & SHD & $5.24 \pm 1.54$ & $5.20 \pm 1.58$ & .524 & .605 \\
\hline & CON & $4.98 \pm .738$ & $4.98 \pm .84$ & .057 & .955 \\
\hline
\end{tabular}

Table 11. Comparison of static and dynamic stability between SHD and CON groups

\begin{tabular}{ccccc}
\hline Variables & $\mathbf{S H D}(\mathbf{n}=\mathbf{2 7})$ & $\mathbf{C O N}(\mathbf{n}=\mathbf{2 6})$ & $\mathbf{t}$ & $\mathbf{p}$ \\
\hline One-leg standing(sec) & $.77 \pm 1.47$ & $.19 \pm 1.47$ & 1.446 & .154 \\
6m-walking(sec) & $-.04 \pm .41$ & $-.00 \pm .41$ & -.329 & .744 \\
\hline
\end{tabular}

\section{혈액변인의 변화}

6 주간의 기능성 소재 섭취 전후의 집단별 혈액반응 을 분석한 결과는 <Figure 6 >, 〈Table 12,13 >과 같다.

젖산 $(\mathrm{uEq} / \mathrm{l}) \mathrm{SHD}$ 군은 - $.049 \pm 0.12$ 감소하였고 $\mathrm{CON}$ 군은 $.048 \pm 0.21$ 증가하여 두 처치집단 간에 통계적으 로 유의한 차이가 났다 $(\mathrm{p}=.044)$. 집단내에서는 SHD군

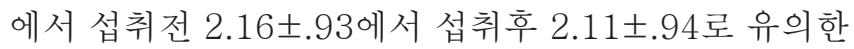
감소를 나타냈다 $(\mathrm{p}=.049)$. 반면 $\mathrm{CON}$ 군에서는 섭취 전 후비교에서 유의한 차이가 나타나지 않았다 $(\mathrm{p}=.253)$.

혈당 $(\mathrm{mg} / \mathrm{d} \boldsymbol{\ell})$ 집간단 비교에서 $\mathrm{SHD}$ 군은 $1.88 \pm 7.35$ 감소하였고 $\mathrm{CON}$ 군은 $0.30 \pm 8.33$ 감소하였지만 통계적 유의차는 없었다 $(\mathrm{p}=.467)$. 한편, 집단내 사전대비 사후 변화에서 모두 유의한 차이가 나타나지 않았다.

TG(mg/dl) SHD군은 $13.11 \pm 33.49$ 감소하였고 $\mathrm{CON}$ 군은 $5.61 \pm 41.82$ 감소하였지만 집단간에는 통계 적으로 유의차는 없었다 $(\mathrm{p}=.474)$. 한편, 집단내 사전대 비 사후변화에서 모두 유의한 차이가 나타나지 않았다.

$\mathrm{HDL}(\mathrm{mg} / \mathrm{d} \boldsymbol{\ell}) \mathrm{SHD}$ 군은 $1.59 \pm 3.98$ 증가하였고 $\mathrm{CON}$ 군은 $1.15 \pm 5.89$ 감소하여 두 처치집단 간에 통계적으 로 유의한 결과를 나타내었다 $(\mathrm{p}=.051)$. 집 단내에서는 $\mathrm{SHD}$ 군에서는 6 주간의 섭취전 $51.00 \pm 13.25$ 에서 섭취 후 $52.59 \pm 11.60$ 유의한 증가를 나타냈다 $(\mathrm{p}=.048)$. 반
Table 12. Comparison of exercise performance ability related blood factors within SHD and CON groups

\begin{tabular}{|c|c|c|c|c|c|}
\hline Variable & Group & Pre & Post & $\mathbf{t}$ & $\mathbf{p}$ \\
\hline \multirow{2}{*}{ 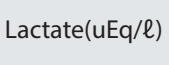 } & SHD & $2.16 \pm .93$ & $2.11 \pm .94$ & 2.064 & .049 \\
\hline & CON & $2.19 \pm .74$ & $2.24 \pm .71$ & -1.171 & .253 \\
\hline \multirow{2}{*}{$\begin{array}{c}\text { Glucose }(\mathrm{mg} / \\
\mathrm{dl})\end{array}$} & SHD & $96.96 \pm 6.46$ & $95.07 \pm 4.64$ & 1.335 & .193 \\
\hline & CON & $97.38 \pm 6.78$ & $97.07 \pm 10.54$ & .188 & .852 \\
\hline \multirow{2}{*}{$\mathrm{TG}(\mathrm{mg} / \mathrm{d} \ell)$} & SHD & $143.14 \pm 47.58$ & $130.03 \pm 38.11$ & 2.034 & .052 \\
\hline & CON & $133.11 \pm 63.28$ & $127.50 \pm 41.45$ & .685 & .500 \\
\hline \multirow{2}{*}{$\mathrm{HDL}(\mathrm{mg} / \mathrm{d} \ell)$} & SHD & $51.00 \pm 13.25$ & $52.59 \pm 11.60$ & -2.078 & .048 \\
\hline & CON & $48.30 \pm 7.80$ & $47.15 \pm 8.46$ & .999 & .327 \\
\hline \multirow{2}{*}{$\mathrm{LDL}(\mathrm{mg} / \mathrm{dl})$} & SHD & $117.77 \pm 13.36$ & $116.11 \pm 15.61$ & .717 & .480 \\
\hline & CON & $123.26 \pm 16.29$ & $126.65 \pm 20.59$ & -1.177 & .250 \\
\hline \multirow{2}{*}{$\begin{array}{l}\text { Creatine (mg/ } \\
\mathrm{dl})\end{array}$} & SHD & $91.70 \pm 27.79$ & $100.25 \pm 31.10$ & -1.766 & .089 \\
\hline & CON & $79.30 \pm 21.47$ & $77.15 \pm 18.70$ & .734 & .470 \\
\hline
\end{tabular}

Table 13. Comparison of exercise performance ability related blood factors between SHD and CON groups

\begin{tabular}{ccccc}
\hline Variables & SHD(n=27) & CON(n=26) & $\mathbf{t}$ & $\mathbf{p}$ \\
\hline Lactate $(\mathrm{uEq} / \ell)$ & $-.049 \pm 0.12$ & $.048 \pm 0.21$ & -2.064 & .044 \\
Glucose $(\mathrm{mg} / \mathrm{d} \ell)$ & $-1.88 \pm 7.35$ & $-.30 \pm 8.33$ & -.733 & .467 \\
TG $(\mathrm{mg} / \mathrm{d} \ell)$ & $-13.11 \pm 33.49$ & $-5.61 \pm 41.82$ & -.722 & .474 \\
HDL $(\mathrm{mg} / \mathrm{d} \ell)$ & $1.59 \pm 3.98$ & $-1.15 \pm 5.89$ & 1.995 & .051 \\
LDL $(\mathrm{mg} / \mathrm{d} \ell)$ & $-1.66 \pm 12.07$ & $3.38 \pm 14.66$ & -1.371 & .176 \\
Creatine $(\mathrm{mg} / \mathrm{d} \ell)$ & $8.55 \pm 25.16$ & $-2.15 \pm 14.96$ & 1.874 & .067 \\
\hline
\end{tabular}

면 $\mathrm{CON}$ 군에서는 섭취 전후 비교에서 유의한 차이가 나 타나지 않았다 $(\mathrm{p}=.327)$.

$\mathrm{LDL}(\mathrm{mg} / \mathrm{d} \mathbf{\ell})$ 집간단 비교에서 $\mathrm{SHD}$ 군은 $1.66 \pm 12.07$ 감소하였고 $\mathrm{CON}$ 군은 $3.38 \pm 14.66$ 증가하였지만 통계 적 유의차는 없었다 $(\mathrm{p}=.176)$. 한편, 집단내 사전대비 사 후변화에서 모두 유의한 차이가 나타나지 않았다.

크레아틴 $(\mathrm{mg} / \mathrm{d} \boldsymbol{l})$ 집간단 비교에서 SHD군은 $8.55 \pm 25.16$ 증가하는 경향과 $\mathrm{CON}$ 군은 $2.15 \pm 14.96$ 감소하는 경향을 보였지만, 통계적으로 유의한 차이는 없었다 $(\mathrm{p}=.067)$. 한편, 집단내 사전대비 사후변화에서 모두 유의한 차이가 나타나지 않았다.

\section{논의}

본 실험은 해마추출물의 운동수행능력개선 효과를 평가하기 위하여, 식약처 건강기능식품가이드라인에서 제안하는 운동수행능력의 효능을 검증하는 방법을 기준 

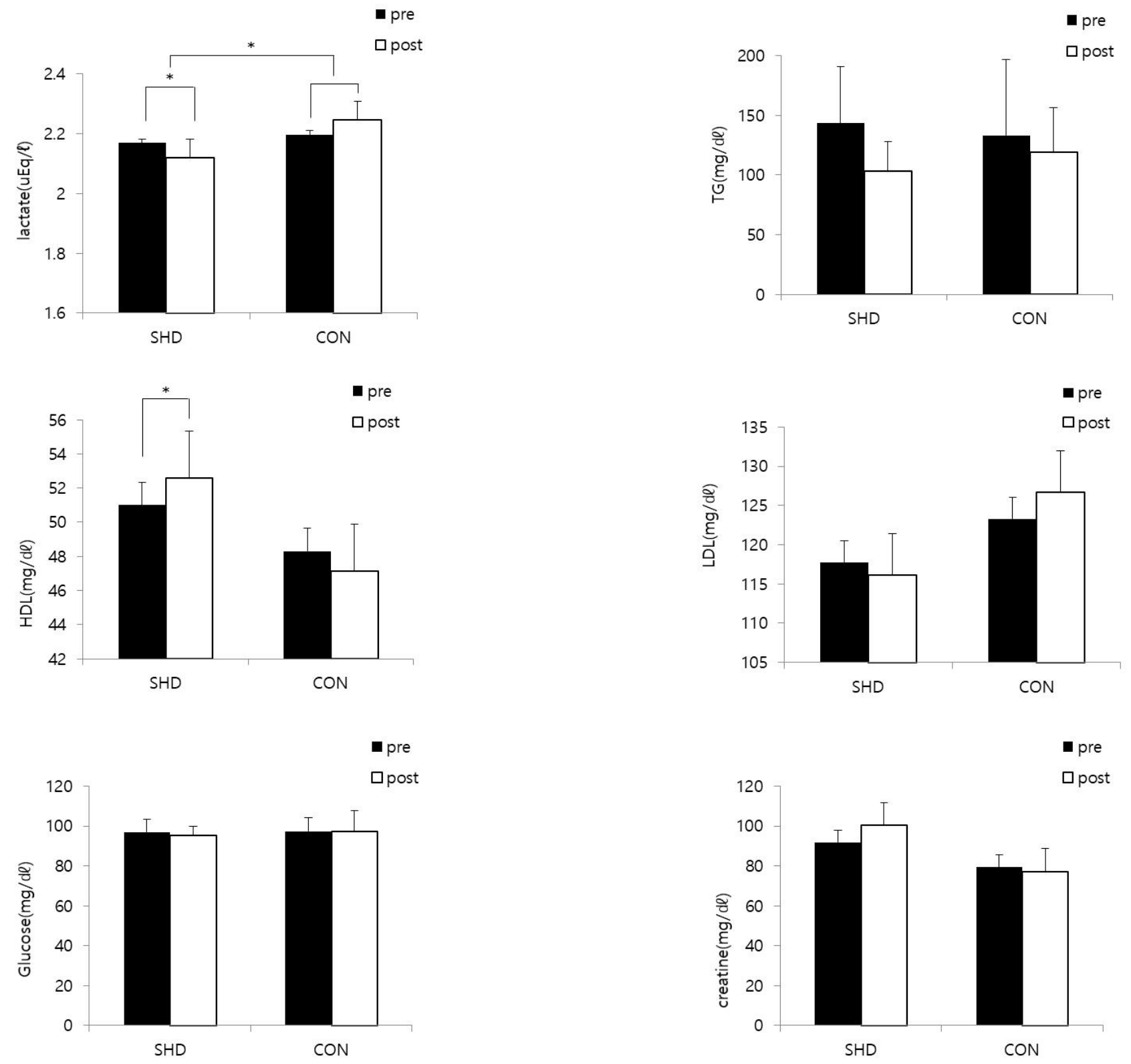

Figure 6. Effect of seahorse extract diet for 8 weeks on exercise performance ability related blood factors in elderly. $\left({ }^{* *} \mathrm{p}<.01\right)$

으로 6 주간의 해마추출물을 식이섭취한 후의 관련 항 목들의 변화를 측정한 결과를 통계 분석하여 개선효과 를 구명하고자 하였다.

\section{신체조성과 근육량}

6주간의 식이섭취 기간 동안 $\mathrm{SHD}$ 군은 해마추출물 섭취에 따라 신체조성별로 구분하여 분석한 결과에 따
르면, 근육량을 의미하는 총제지방량은 SHD군에서 6 주간 해마추출물 섭취 후 증가한 것으로 나타났고, 이 러한 차이에 대한 두 집단간 비교에서도 통계적으로 유 의하게 나타났다. 하지만, 체중과 총지방량에서는 집단 간 및 집단내 유의미한 변화가 없었다. 한편, 근감소증 의 주요 지표인 사지근육량 지수인, 즉 SMI에서는 6주 간의 섭취에 따른 변화가 집간간 및 집단내에서 통계적 
으로 유의차가 나타나지 않았다.

이러한 결과는 해마 추출물이 체중과 체지방의 개선효 과는 부족한 것으로 여겨지며, 체중과 키의 변화로 유도 되는 사지근육량에서는 변화가 나타나지 않았다. 따라서 6주간의 해마추출물 섭취는 Lee et al. [9]의 이전 연구에 서 확인한 8주간의 해마섭취 효과와 함께 노인들에게서 근육의 양적 증가시킬 수 있는 가능성을 지지한다.

\section{근체력}

근육의 양적변화와 함께 낙상예방에 결정적인 역할을 하는 근육의 기능을 노인의 근체력 검사를 통해 실시한 결과에 따르면, 근지구력을 나타내는 윗몸일으키기가 유 의하게 증가했다. 각 처치집단 내에서는 $\mathrm{SHD}$ 군에서 6 주 간의 식이처치에 따라 윗몸일으키기 횟수가 유의하게 증 가한 반면에 $\mathrm{CON}$ 군에서는 유의한 변화는 없었다. 하지 만, 상지근력이 상대적으로 부족한 노인에게 어려운 근지 구력 측정 과제인 팔굽혀펴기, 근력을 측정하는 배근력과 악력에서 모두 6주간의 식이처치에 따른 $\mathrm{SHD}$ 군 및 $\mathrm{CON}$ 군의 집단간 차이와 집단내 차이를 관찰하지 못했다. 이 러한 결과는 근육량의 부분적인 개선 효과와 관련성이 있 을 수 있다. 따라서 6 주간의 해마추출물섭취를 통해 노인 들의 근력보다는 근지구력에 대한 개선 가능성이 있음을 의미한다. 이러한 결과는 6 주 이상의 해마추출물 섭취를 통해 근력보다는 일상생활능력에 보다 근지구력이 중요 한 노인들에게 보다 적절한 근기능의 변화가 나타날 수 있음을 시사한다.

근육의 질적 특성을 분석해내는 등속성 근력에서, 근 지구력(180deg/sec \%RVC) 발휘 상태에서 섭취집단 모두 집단간 유의한 증가를 나타냈고, 이들의 집단내 변화에서는 6 주간 해마추출물을 섭취한 $\mathrm{SHD}$ 군에서 유 의한 증가가 나타났다. 이러한 결과는 해마추출물 섭취가 체중을 이용한 등장성 근지구력 증가와 함께 등속성 근 력를 통해 분석된 질적개선 효과를 확인할 수 있다. 따 라서 6주간의 해마추출물 섭취는 이전에 실시한 Lee et al. [9]의 연구와 유사하게 노인들에게서 근육의 양적 및 질적 개선을 보였으며, 이러한 경향은 최종적으로 근 기능 개선을 통한 일상생활능력 향상에 이르는 일련의 긍 정적 효과[13]에 대한 가능성을 시사한다.

\section{심폐기능 및 자율신경계}

심폐체력 및 자율신경계의 심박 조절기능을 확인 하기 위한 심박수와 심박변이도의 변화분석에서는, 6 주간
의 해마섭취를 실시한 $\mathrm{SHD}$ 군 $\mathrm{CON}$ 군에 비해 통계적 으로 유의미하게 심박수가 낮게 나타났고, $\mathrm{SDNN}$ 이 높 게 나타났다. 한편, 집단내에서 6주간의 식이처치에 따른 전후 변화를 비교한 결과에서는 $\mathrm{SHD}$ 군과 $\mathrm{CON}$ 군 모두 심박수의 유의한 변화가 나타나지 않았고, 심 박변이도 중 $\mathrm{SDNN}$ 에서는 $\mathrm{CON}$ 군에서 유의한 감소가 나타났다. 이러한 결과는 이전의 고혈압 노인환자의 유산소성 운동이 갖는 심폐기능의 안정과 자율신경계 의 조절기능의 긍정적 개선효과[12]를 해마추출물 섭 취를 통해서도 기대할 수 있게 한다.

\section{평형성}

근육의 양적, 질적 기능과 함께 노인의 일상생활능 력과 낙상 예방에 중요한 역할을 하는 평형성은 정적 (한발서기) 및 동적(6m걷기 보행시간) 평형성에서 모 두 집단간 유의미한 경향이 나타나지 않았다. 하지만, $\mathrm{SHD}$ 군 내에서 낙상 예방에 중요한 체력요소가 될 수 있는 한발서기에서는 6주간의 해마섭취 후에 통계적으 로 유의한 증가를 나타냈다. 이러한 결과는 이전에 노 인들을 대상으로 실시된 평형성 연구[14]와 함께 종합 해보면, 근지구력의 부분적인 개선과 근신경계 활성도 의 일부 개선효과에 따라, 평형능력이 부분적 개선된 것으로 예상할 수 있다. 따라서 6주간의 해마추출물 섭 취는 노인의 일상생활능력에 필요한 체력들 중에서 부분적으로 정적 평형능력에서의 개선 가능성을 제시 한다.

\section{운동능력 관련 혈액변인}

6 주간의 식이처치에 따른 혈중젖산 농도의 변화에 서 $\mathrm{SHD}$ 군은 $\mathrm{CON}$ 군에 비해 유의한 감소가 나타났다. $\mathrm{SHD}$ 군 내에서 6주간의 해마추출물 섭취 후에 혈중 젖 산 농도가 유의하게 감소했고 $\mathrm{CON}$ 군에서는 유의하게 증가했다. 이러한 결과는 무산소성대사 감소에 따른 에너지생산/공급의 효율성과 부분적인 대사불균형에 대한 개선효과의 가능성을 시사한다. HDL 콜레스테롤 은 6주간의 식이처치 후 집단 간에서도 통계적으로 유 의한 차이를 나타냈으며, SHD군 내에서도 섭취 전후 에서 통계적 유의한 증가를 나타냈다. 이는 기능성 소 재 식품 섭취가 혈중지질 프로필에 긍정적인 영향을 미치는 HDL 콜레스테롤의 증가를 유도하는 것으로 판 단된다.하지만, 6 주간의 해마추출물 섭취에 따른 집단 간 및 집단내 변화를 비교한 결과에 따르면, 에너지 대 
사에 필요한 특히 $\mathrm{LDL}, \mathrm{TG}$, 포도당과 같은 주요 기질 들의 혈중 수준에 대한 통계적 유의차를 발견하지 못했 다. 또한 강한 운동수행에 대한 에너지 공급에 관여하 는 혈중 크레아틴의 수준도 6 주간의 해마추출물 섭취 에 따른 집단간 및 집단내 통계적 유의성을 관찰하지 못했다.

종합해보면, 6주간의 해마추출물 섭취는 혈중 젖산 감소와 $\mathrm{HDL}$ 콜레스테롤 수준의 증가는 부분적인 대사 기능의 개선과 체력수준 향상에 긍정적인 요인으로 Lee et al. [9]의 연구결과와 유사한 경향을 보인다. 이러한 경향을 통해, 해매추출물은 노인의 대사기능 [15], 체력 및 운동기능 등 일상생활능력(ADL)을 좌 우하는 기능 $[15,16]$ 에 관한 여러 유사한 기능성 식품 과 같은 과학적 검증을 거친 효능을 보이는 것으로 여 겨진다.

따라서 본 연구결과는 특히, 노인들을 대상으로 근 육의 퇴행에 따른 양적, 질적 변화를 개선하기 위해 장 기간의 식용해마 섭취가 생리학적 변인에 미치는 효과 를 구명한 운동과학적 연구가 매우 부족한 현실에서, 6 주간의 해마 추출물 섭취가 신체조성 중에서 나타난 근육량 개선, 근활성도를 통한 체성신경계와 심박변이 도를 통한 자율신경계의 변화에서 예측되는 근신경계의 질적 개선, 그리고 이와 관련된 혈중 기질 수준 및 에 너지 공급 요인의 개선효과를 부분적으로 갖을 수 있 음을 지지한다.

\section{결론}

이 연구의 결과들을 요약하면, 6 주간의 식용해마추 출물의 섭취를 통해 노인들의

1. 총제지방량(근육량) 증가, 체중을 이용한 등장성 및 등속성 근지구력 등의 증가를 통한 근육의 양적 및 질적 변화가 일어났다.

2. 한발서기시간 증가를 통한 정적 평형성 개선 효 과와, 심박수의 감소와 $\mathrm{SDNN}$ 증가를 통한 자율신경계 의 일부 개선 효과가 나타났다.

3. 혈중 젖산 수준 감소와 $\mathrm{HDL}$ 콜레스테롤 증가 등 혈중 대사기능 일부가 개선되었다.

이러한 일련의 변화들은 6 주간의 식용해마 섭취가 노인들의 일상생활 능력과 식약처 건강기능식품가이 드라인에서 제안하는 운동수행능력에 대해서 일부개 선효과를 나타낼 가능성을 시사한다.

\section{Acknowledgments}

This research was supported by Kyungsung University Research Grants in 2017.

\section{Conflicts of Interest:}

The author declares no conflict of interest.

\section{References}

1.KCD C, 2016 ; http://ww w.cdc.go.kr/ CDC/ contents / C d c Kr ContentView. jsp?menuIds=HOME006-MNU3003-MNU3006MNU3013\&cid=121153\&busiType=6. (Accessed Apr 11, 2018).

2. Bijlsma AY, Meskers CG, Westendorp RG, Maier AB. Chronology of age-related disease definitions: osteoporosis and sarcopenia. Ageing Res Rev. 2012; 11(2):320-324.

3. Doherty TJ. Invited review: aging and sarcopenia. J Appl Physiol. 2003; 95(4):1717-1727.

4. Evans WJ. Skeletal muscle loss: cachexia, sarcopenia, and inactivity. Am J Clin Nutr. 2010; 91(4):1123S-1127S.

5. Sanaye SV, Pise NM, Pawar AP, et al. Evaluation of antioxidant activities in captive-bred cultured yellow seahorse Hippocampus kuda (Bleeker 1852). Aquaculture. 2014; 434(20):100-107.

6. Kim HS, Shin B, Kim SY, et al. Antioxidant Activity of Pepsin Hydrolysate Derived from Edible Hippocampus abdominalis in vitro and in Zebrafish Models. Korean J Fish Aquat Sci. 2016; 49(4):445-453.

7. Nokia MS, Lensu S, Ahtiainen JP, et al. Physical exercise increases adult hippocampal neurogenesis in male rats provided it is aerobic and sustained. J Physiol. 2016; 594(7):1855-73.

8. Yang HW, Kim EA, Kim SY, Jeon YJ. Acute Toxicity Assessment in Zebrafish Danio rerio of Arsenic-rich Extracts from Three Species of Seaweeds. Korean J Fish Aquat Sci. 2018; 51(1):31-41.

9. Lee BJ, Park CH, Jeon BH. Effects of Seahorse 
Supplementation on muscle mass, exercise performanceabilities and their related blood factors in healthy elders. JF M SE. 2018; 30(2):409-421

10. National Institute of Food and Drug Safety Evaluation, 2016; http://nifds.go.kr/brd/m_15/view.do?seq=100 $51 \& \operatorname{srchFr}=\& \operatorname{srchTo}=\& \operatorname{srch} W o r d=\& \operatorname{srchTp}=\& \mathrm{itm}_{-}$ seq_1=0\&itm_seq_2 $=0 \&$ multi_itm_seq=0\&company_ $\mathrm{cd}=\&$ company_nm $=\&$ page $=21$. (Accessed Apr 11, 2018).

11. Kell RT, Bell G, Quinney A. Musculoskeletal fitness, health outcomes and quality of life. Sports Med. 2001; 31(12):863-73.

12. Kang SJ, Kim BR, Kim SJ, et al. The Effects of 12-Weeks Aerobic Exercise in Elder Hypertension Patients on Pulse Pressure and Heart Rate Variability. Asian J
Kinesiol. 2010; 12(1):47-54.

13. Hong JY, Cho JH. Effects of Combined Exercise on the Skeletal Muscle Mass Index and Balance Scale of Elderly Women with Sarcopenia. Asian J Kinesiol. 2015; 17(3):17-24.

14. Choi WC, Reid SN, Ryu JK, Kim Y, Jo YH, Jeon BH. Effects of $\gamma$-aminobutyric acid-enriched fermented sea tangle (Laminaria japonica) on brain derived neurotrophic factor-related muscle growth and lipolysis in middle aged women. Algae. 2016; 31(2): 175-187.

15. Jeon BH. Effects of GABA enriched fermented sea tangle supplementation on body composition, muscular activity, muscle growth factors, and inspiration functions in adult males. Asian J Kinesiol. 2017; 19(1):1-9. 